\title{
Investigation of the influence of critical process parameters in roller compaction process on physical properties of granules and tablets using design of experiments
}

\author{
Elizabeta Atanaskova*, Dejan Kostovski, \\ Natasa Anevska-Stojanovska \\ Research and Development, Alkaloid AD-Skopje, Bul. Aleksandar Makedonski 12, \\ 1000 Skopje, Republic of North Macedonia
}

*Corresponding author: Elizabeta Atanaskova, e-mail: eatanaskova@Alkaloid.com.mk

\begin{abstract}
Different granulation methods are used in the pharmaceutical industry, mainly divided as wet or dry granulation. Although roller compaction is a widely used dry granulation process, the evaluation of critical process parameters has proven challenging because of the complex interactions among each parameter. Ribbons with different properties based on the variation of the input parameters are the result of roller compaction process. The properties of the final product are directly related to process parameters used during dry granulation. Understanding the interaction between the roller compaction parameters will allow accurate control of the process.

The study aims to present the applicability of design of experiments (DoE) approach in the development of the roller compaction process. For this purpose, the two-level full factorial design was used to evaluate the influence of process parameters as roll pressure and speed, vertical feed screw speed and mill speed on the intermediate and final product physical properties.

The results revealed that roll speed is the variable having the most impact on the density of the granules. The granules particle size is mostly dependent on variation in roll pressure, roll speed, and mill speed. Increasing the milling speed will create more uniform particles in the aspect of span distribution. After the process of compression of granules into tablets and assessing the data, roll speed was identified as the most influencing factor regarding tablet hardness.

Keywords: roll compaction, dry granulation, design of experiments, product physical properties.
\end{abstract}




\section{INTRODUCTION}

Different granulation methods are used in the pharmaceutical industry in order to enlarge fine powders into granules. Numerous advantages can be attributed to performing the extra processing step, such as improved material flow, densification, desired particle size distribution, a decrease of fines, etc. The granulation, in general, can be divided into two major types: wet methods, which utilize some form of liquid to bind the primary particles, and dry methods, which do not utilize any liquid (1). Since dry granulation does not use any liquids (organic and/or non-organic) it can be suitable to use for active components sensitive to moisture and/or increased temperature. Roller compaction technology is well suited for dry granulation in the era of the modern development of active pharmaceutical ingredients and the design of modern pharmaceutical plant (2). During roller compaction, a powder is fed between two counterrotating rolls. As the powder is pushed between the rolls, it becomes compacted. The compacted powder exits the rolls as a ribbon, or briquette, and then is milled to the desired granule size before tableting (3).

The bonding mechanisms occurring during dry granulation are a mixture of Van der Waals' forces, mechanical interlocking, and a recombination of bonds established between freshly created surfaces and solid bridges, created because of partial melting and solidification during compression (4).

A successful compaction process is a complex balance between formulation and materials, machine design and identifying the critical process parameters in the process and their optimisation to obtain a product with the desired characteristics. Although the process itself is performed at relatively high pressure, the absence of granulation liquid necessitates the excipients having good compression properties, thus the resulting granules will be influenced by the powder cohesiveness, density, flow characteristics, and powder particle size distribution.

Different roller compactor designs exist, offering different solutions for the hopper and screw system, roller configuration, etc. However, most of the modern ones are characterized by the addition of a software control unit, used to regulate and monitor mechanical parts and translate signals from various sensors into data. With the possibility of assessing this data and having precise control of the process with the equipment, the current study was intended to use the statistical design of experiments (DoE) to examine the influence of the critical process parameters in the process of roller compaction on the physical characteristics on the granulate. Additionally, the granules were compressed on a rotary tablet press, investigating the influence of different granule properties on the process of tablet manufacturing. 


\section{MATERIALS AND METHODS}

\section{MATERIALS}

All materials used in the study were of European pharmacopoeia grade (5). The formulation was comprised as a placebo, containing $\alpha$-Lactose monohydrate (FlowLac 100, MEGGLE Wasserburg GmbH \& Co. KG), Microcrystalline cellulose (Avicel PH102, DuPont Nutrition \& Health), Croscarmellose sodium (Ac-Di-Sol, DuPont Nutrition \& Health), Crosslinked PVP (Kollidon CL, BASF SE), Anhydrous colloidal silicon dioxide (Aerosil 200, Evonik Industries AG), Glyceryl dibehenate (Compritol 888ATO, Gattefossé SAS).

\section{METHODS AND EQUIPMENT}

\section{Mixing}

Initial excipient blend, unlubricated blend and final blend were prepared using Erweka AR 400 Drum hoop mixer (ERWEKA GmbH). Mixing drum of 10L was used and the rotation of the hoop was set appropriately to achieve uniform displacement of mixing material.

Initial excipient blend for roll compaction was composed of $\alpha$-Lactose monohydrate, Microcrystalline cellulose, Crosslinked PVP and Anhydrous colloidal silicon dioxide at $35.60 \%, 53.40 \%, 3.00 \%$ and $0.50 \%(\mathrm{w} / \mathrm{w})$ respectively. Mixing time for preparation of the initial excipient blend was 10 minutes. Additional excipients (Microcrystalline cellulose and Croscarmellose sodium at $4.50 \%$ and $2.00 \%(\mathrm{w} / \mathrm{w})$ ) were added to the resulting granules after the compaction and milling process and mixed into an unlubricated blend for 20 minutes. Subsequently, 1.00\% (w/w) Glyceryl dibehenate was added and the final blend was mixed for 5 minutes.

\section{Roller compaction}

The roller compactor used was Fitzpatrick IR220 Chilsonator (The Fitzpatrick Company, IDEX MPT Inc.). The rolls had $2 \mathrm{~cm}$ width and $20 \mathrm{~cm}$ roll diameter, with circumferential grooved surfaces. Subsequent in-line milling was performed using a FitzMill model L1A mill knives and $1.651 \mathrm{~mm}$ screen. The horizontal feeding screw was kept constant. Single sieve size was used for all cases.

\section{Powder and granules characterization techniques}

After compacting and milling, physical tests on the granules were performed. The powder was characterized using the method for determination of bulk and tapped density according to the current edition of the Ph. Eur (5). 
Bulk density was determined by filling a $100 \mathrm{ml}$ cylinder with the granule to approximately $100 \mathrm{~mL}$ mark. The weighted mass of the cylinder with a $100 \mathrm{ml}$ sample was used to calculate the bulk density.

The tapped density was determined by tapping the graduated cylinder previously filled with the $100 \mathrm{ml}$ powder for 1250 tabs using the tap density tester (Erweka SVM 102 tester (ERWEKA GmbH)).

Particle size distribution was determined according to the analytical sieves method from Ph. Eur (5), using Retsch analytical sieve-shaker AS 400 (Retsch GmbH).

The particle size distribution of each granule was analyzed on a sieve-shaker using series of sieves with different sizes $(80 \mu \mathrm{m}, 125 \mu \mathrm{m}, 200 \mu \mathrm{m}, 315 \mu \mathrm{m}, 630 \mu \mathrm{m}, 800 \mu \mathrm{m}$, $1000 \mu \mathrm{m})$. A representative sample of $50 \mathrm{~g}$ of the material was placed on the top sieve from the nest of sieves with descended degrees of coarseness. Sieving time for performing the analysis was 5 minutes and shaking amplitude was $1.5 \mathrm{~mm}$. After finishing the analysis, the quantity of material retained on each sieve was determined. Literature sources (6-8) define the fine and coarse fractions differently. However, in this study authors chose the definition that a fraction of granules smaller than $125 \mu \mathrm{m}$ were fines and larger than 315 $\mu \mathrm{m}$ were coarse. The desired outcome of the granulation process would be to have fewer fines and as much as possible coarse particles.

In order to describe the quantity distribution width, the span value was calculated according to the formula:

$$
\text { Span }=[(\mathrm{D} 90-\mathrm{D} 10) / \mathrm{D} 50](9)
$$

The calculation of the span value is done by the EasySieve (Retsch GmbH) software and exported as result sheet.

\section{Tablet compression}

The lubricated final blend was tablet compressed on Korsch Xl 100 Pro rotary tablet press (Korsch AG), equipped with four $7 \mathrm{~mm}$ flat punches and gravity feeder configuration, at a production rate of $20 \mathrm{rpm}$. The edge thickness was adjusted for every case to have a constant main compression pressure of $10 \mathrm{kN}$. Pre-compression was also fixed at $0.2 \mathrm{kN}$, and the filling depth was also constantly adjusted so that the resulting tablets have an average mass of $120 \mathrm{mg}$. Tablet compressing was performed on constant production speed and compression pressure.

Tablet weight was measured using analytical balance Sartorius model SECURA224-1CEU (Sartorius AG), hardness and thickness were measured using Erweka TBH 425 multitester (ERWEKA GmbH).

Tablet disintegration time was determined according to standard basket-rack assembly Ph. Eur method (5) for tablets and capsules of normal size using Erweka Type ZT302 disintegration tester. 
The process flow with the process parameters and material attributes tested throughout all of the phases is graphically presented in Figure1.

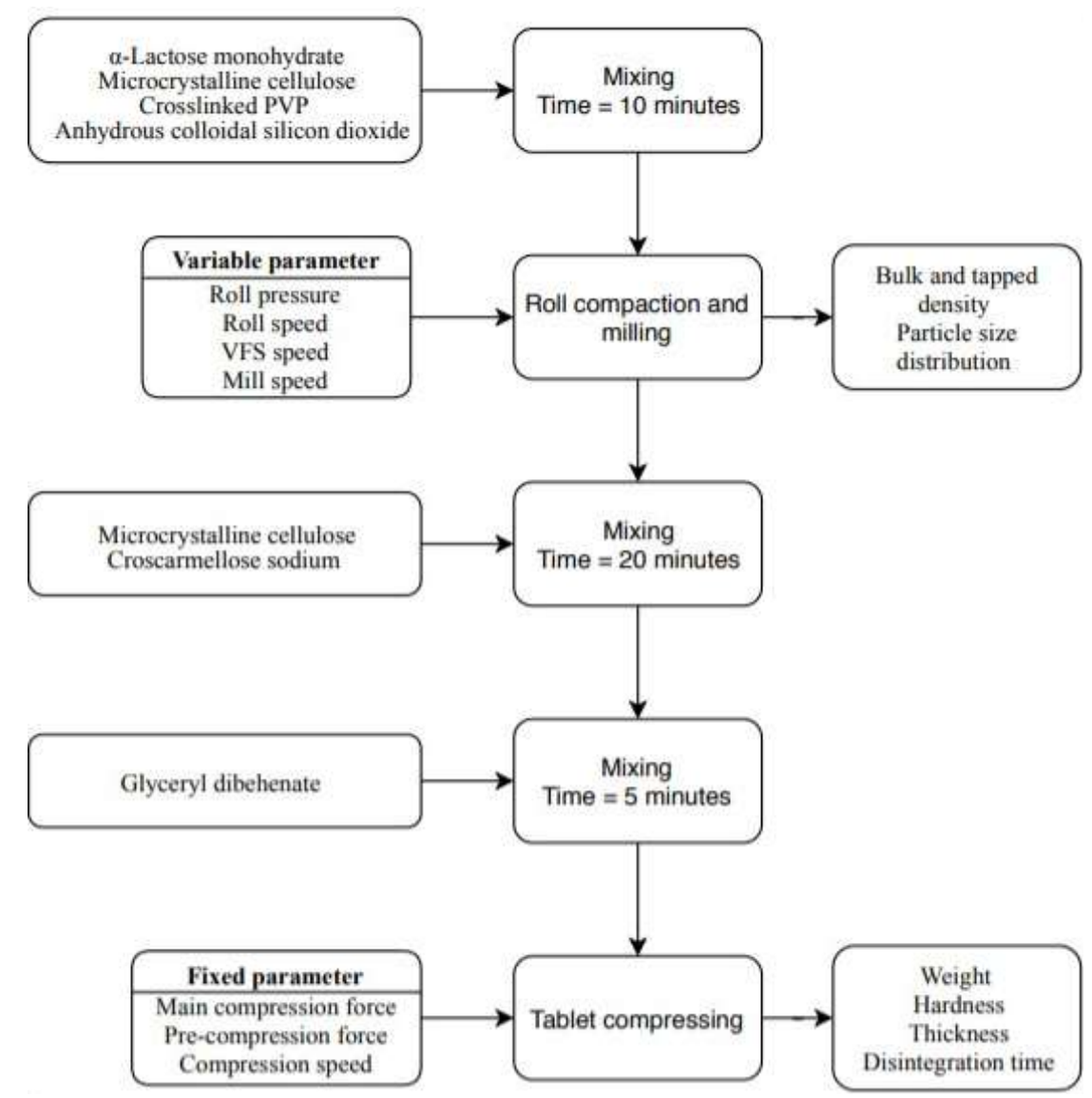

Figure 1 Illustration of the study process

\section{Design of experiments}

Full factorial design at two levels, for four identified critical process parameters, was used to assess the main effects and interactions. According to the roller compactor design used in this study, the main effects chosen for investigation were roll pressure, roll speed, vertical feeding screw speed, and mill speed. Design-Expert software (Stat-Ease Inc.) was used to create the experimental design at two levels and four center points. A total of 20 runs were performed. The coded variables were substituted with the values for minimum and maximum value, previously set according to manufacturer recommendations, literature data, and trials and are presented in Table I. 
Table I Variable values

\begin{tabular}{|c|c|c|c|c|c|c|c|c|}
\hline Factor & Name & Units & Type & Low Actual & High Actual & Low Coded & High Coded & Mean \\
\hline A & Roll pressure & bar & Numeric & 20 & 40 & -1 & +1 & 30 \\
\hline B & Roll speed & rpm & Numeric & 3 & 12 & -1 & +1 & 7.5 \\
\hline C & VFS speed & rpm & Numeric & 50 & 200 & -1 & +1 & 125 \\
\hline D & Mill speed & rpm & Numeric & 1000 & 3000 & -1 & +1 & 2000 \\
\hline
\end{tabular}

\section{FORMULATION}

The qualitative and quantitative composition of the formulation is presented in Table II.

Table II Qualitative and quantitative composition of the mixture

\begin{tabular}{|c|c|c|}
\hline Component & \% in formulation & \multirow{2}{*}{ Comment } \\
\hline$\alpha$-Lactose monohydrate & 35.60 & \\
\hline Microcrystalline cellulose & 53.40 & \\
\hline Crosslinked PVP & 3.00 & \multirow{2}{*}{ Added for Final blend } \\
\hline $\begin{array}{c}\text { Anhydrous colloidal } \\
\text { silicon dioxide }\end{array}$ & 0.50 & \\
\hline Microcrystalline cellulose & 4.50 & \\
\hline Croscarmellose sodium & 2.00 & \\
\hline Glyceryl dibehenate & 1.00 & \\
\hline
\end{tabular}

The mixture is mostly composed of Lactose monohydrate and Microcrystalline cellulose as fillers, industry's most used fillers for direct compression (10). Microcrystalline cellulose has extremely good binding properties, additionally working as a disintegrant and lubricant (11). Microcrystalline cellulose is known for permanent deformation by nonspecific plastic flow (12). The plasticity of the Microcrystalline cellulose rises with the compressing force increase (13). However, the crushing strength 
of compacts is decreased with increasing of the compaction speed, caused by the increased porosity of the compacted powder bed (14). As an effect of its plastic behavior, Microcrystalline cellulose is sensitive to mixing with lubricants (15). The raise in compaction load produces an increase in the disintegration time as an effect of the decreased water penetration $(16,17)$.

Lactose monohydrate has good flowability and high packing density because of the regular form of the particles (18-20). Experimental work from many authors shows that Lactose monohydrate consolidates mainly by fragmentation (21-24), with relatively poor binding properties (25). Lactose compacts disintegrate very quickly in water as a result of rapid liquid uptake and fast dissolution of the bonds (26).

In practice, Lactose monohydrate is often used with Microcrystalline cellulose $(15,27)$. This combination results in a strong synergistic effect on disintegration time, whereas the crushing strength increases proportionally to the percentage of Microcrystalline cellulose (15). Therefore, the mixture of Lactose monohydrate and Microcrystalline cellulose is one of the more popular blends in direct compression.

Crosslinked PVP, grade CL is well known for binding capability and dissolution performance. Colloidal silicon dioxide has been known as a glidant to optimize the flow of powders since the earliest days of direct compression. Croscarmellose sodium is chosen as a disintegrant in the outer phase, while Glyceryl dibehenate is chosen as a widely used lubricant in tablet compressing processes.

\section{RESULTS AND DISCUSSION}

Full design is presented in Table III, with values for the input variables and the measured responses as physical properties of the compacted material and pre-compaction mixture. The authors chose the full factorial design to have more runs and data, and as much information on possible interactions. 
Table III Full design for main effects with input variables and measured responses

\begin{tabular}{|c|c|c|c|c|c|c|c|c|c|c|}
\hline \multirow[b]{2}{*}{ Run } & \multicolumn{4}{|c|}{ Input variables } & \multicolumn{6}{|c|}{ Measured responses } \\
\hline & $\begin{array}{c}\text { Roll } \\
\text { pressure } \\
(\text { Bar) }\end{array}$ & $\begin{array}{l}\text { Roll } \\
\text { speed } \\
\text { (rpm) }\end{array}$ & $\begin{array}{l}\text { VFS } \\
\text { speed } \\
(\mathrm{rpm})\end{array}$ & $\begin{array}{l}\text { Mill } \\
\text { speed } \\
(\mathrm{rpm})\end{array}$ & $\begin{array}{c}\text { Bulk } \\
\text { density } \\
(\mathrm{g} / \mathrm{ml})\end{array}$ & $\begin{array}{l}\text { Tapped } \\
\text { density } \\
(\mathrm{g} / \mathrm{ml})\end{array}$ & $\begin{array}{c}\text { PSD } \\
\text { analysis } \\
\text { fines \% } \\
(<125 \mu \mathrm{m})\end{array}$ & $\begin{array}{c}\text { PSD } \\
\text { analysis } \\
\text { coarse \% } \\
(>315 \mu \mathrm{m})\end{array}$ & $\begin{array}{l}\text { PSD } \\
\text { Span }\end{array}$ & $\begin{array}{c}\text { Tablet } \\
\text { Hardness } \\
(\mathrm{kP})\end{array}$ \\
\hline 1 & 20 & 3 & 200 & 1000 & 0.540 & 0.650 & 45.50 & 25.40 & 5.300 & 7.79 \\
\hline 2 & 40 & 3 & 50 & 1000 & 0.613 & 0.766 & 43.30 & 34.50 & 6.689 & 6.68 \\
\hline 3 & 40 & 12 & 50 & 3000 & 0.480 & 0.580 & 50.10 & 9.30 & 2.227 & 8.92 \\
\hline 4 & 40 & 12 & 200 & 1000 & 0.500 & 0.620 & 46.40 & 18.70 & 4.715 & 8.06 \\
\hline 5 & 30 & 7.5 & 125 & 2000 & 0.550 & 0.700 & 41.80 & 30.10 & 4.866 & 6.95 \\
\hline 6 & 20 & 3 & 200 & 3000 & 0.515 & 0.644 & 45.60 & 18.00 & 3.329 & 7.49 \\
\hline 7 & 20 & 3 & 50 & 3000 & 0.556 & 0.670 & 44.90 & 17.30 & 3.238 & 3.44 \\
\hline 8 & 30 & 7.5 & 125 & 2000 & 0.540 & 0.680 & 40.40 & 29.30 & 4.525 & 6.23 \\
\hline 9 & 30 & 7.5 & 125 & 2000 & 0.540 & 0.670 & 45.40 & 26.30 & 5.177 & 6.88 \\
\hline 10 & 20 & 12 & 50 & 1000 & 0.520 & 0.650 & 46.10 & 20.50 & 5.081 & 6.33 \\
\hline 11 & 40 & 12 & 200 & 3000 & 0.500 & 0.600 & 51.50 & 8.70 & 2.237 & 7.44 \\
\hline 12 & 20 & 12 & 200 & 1000 & 0.510 & 0.610 & 46.60 & 18.90 & 4.729 & 8.34 \\
\hline 13 & 20 & 12 & 50 & 3000 & 0.470 & 0.570 & 52.00 & 8.10 & 2.188 & 8.93 \\
\hline 14 & 20 & 12 & 200 & 3000 & 0.480 & 0.590 & 51.30 & 8.50 & 2.213 & 8.38 \\
\hline 15 & 20 & 3 & 50 & 1000 & 0.581 & 0.735 & 45.90 & 27.80 & 6.347 & 6.70 \\
\hline 16 & 30 & 7.5 & 125 & 2000 & 0.550 & 0.690 & 42.30 & 29.00 & 4.783 & 6.37 \\
\hline 17 & 40 & 3 & 200 & 1000 & 0.580 & 0.720 & 44.40 & 32.30 & 6.370 & 7.09 \\
\hline 18 & 40 & 3 & 50 & 3000 & 0.642 & 0.783 & 38.90 & 33.60 & 4.043 & 5.61 \\
\hline 19 & 40 & 3 & 200 & 3000 & 0.603 & 0.717 & 36.60 & 31.20 & 3.620 & 6.02 \\
\hline 20 & 40 & 12 & 50 & 1000 & 0.470 & 0.580 & 45.50 & 17.30 & 4.278 & 8.89 \\
\hline Blend & 1 & 1 & 1 & I & 0.441 & 0.525 & 58.80 & 1.10 & 1.456 & 13.09 \\
\hline
\end{tabular}

All model equations, $\mathrm{F}$ and $\mathrm{p}$-values, $\mathrm{R}^{2}$ and Adjusted $\mathrm{R}^{2}$ are shown in Table IV. 
Table IV Model summary for response variables

\begin{tabular}{|c|c|c|c|c|c|}
\hline Bulk Density & $\begin{array}{c}\text { F } \\
\text { Value }\end{array}$ & $\begin{array}{c}\text { p-value } \\
\text { Prob }>\text { F }\end{array}$ & R-Squared & Adj R-Squared & $\begin{array}{c}\text { Model equation in terms } \\
\text { of coded factors }\end{array}$ \\
\hline Model & 77.82 & $<0.0001$ & 0.98 & 0.97 & \multirow{9}{*}{$\begin{array}{c}\text { Bulk density }=+0.54+ \\
0.013 * \mathrm{~A}-0.044 * \mathrm{~B}- \\
6.500 \mathrm{E}-003 * \mathrm{C}-4.250 \mathrm{E}- \\
003 * \mathrm{D}-0.017 * \mathrm{~A} * \mathrm{~B}+ \\
0.012 * \mathrm{~A} * \mathrm{D}+0.013 * \mathrm{~B} * \mathrm{C}\end{array}$} \\
\hline A-Roll pressure & 35.96 & $<0.0001$ & & & \\
\hline B-Roll speed & 377.66 & $<0.0001$ & & & \\
\hline C-VFS speed & 8.34 & 0.0148 & & & \\
\hline D-Mill speed & 3.56 & 0.0857 & & & \\
\hline $\mathrm{AB}$ & 58.71 & $<0.0001$ & & & \\
\hline $\mathrm{AD}$ & 28.41 & 0.0002 & & & \\
\hline $\mathrm{BC}$ & 32.08 & 0.0001 & & & \\
\hline Lack of fit & 2.97 & 0.2005 & & & \\
\hline \multicolumn{6}{|l|}{ Tapped Density } \\
\hline Model & 31.04 & $<0.0001$ & 0.95 & 0.92 & \multirow{9}{*}{$\begin{array}{c}\text { Tapped density }=+0.66 \\
+0.015 * \mathrm{~A}-0.055 * \mathrm{~B}- \\
0.011 * \mathrm{C}-0.011 * \mathrm{D}- \\
0.020 * \mathrm{~A} * \mathrm{~B} \\
+0.010 * \mathrm{~A} * \mathrm{D}+0.016 * \mathrm{~B} * \mathrm{C}\end{array}$} \\
\hline A-Roll pressure & 11.92 & 0.0054 & & & \\
\hline B-Roll speed & 152.97 & $<0.0001$ & & & \\
\hline C-VFS speed & 6.54 & 0.0266 & & & \\
\hline D-Mill speed & 6.12 & 0.0309 & & & \\
\hline $\mathrm{AB}$ & 20.88 & 0.0008 & & & \\
\hline $\mathrm{AD}$ & 5.32 & 0.0416 & & & \\
\hline $\mathrm{BC}$ & 13.51 & 0.0037 & & & \\
\hline Lack of fit & 2.27 & 0.2703 & & & \\
\hline \multicolumn{6}{|l|}{ PSD Fines } \\
\hline Model & 18.01 & $<0.0001$ & 0.87 & 0.83 & \multirow{7}{*}{$\begin{array}{c}\text { PSD fines }=+45.91- \\
1.33 * \mathrm{~A}+2.77 * \mathrm{~B}+0.45 * \mathrm{D} \\
+1.01 * \mathrm{~A} * \mathrm{~B}+2.09 * \mathrm{~B} * \mathrm{D}\end{array}$} \\
\hline A-Roll pressure & 10.51 & 0.0064 & & & \\
\hline B-Roll speed & 46.11 & $<0.0001$ & & & \\
\hline D-Mill speed & 1.21 & 0.2908 & & & \\
\hline $\mathrm{AB}$ & 6.14 & 0.0277 & & & \\
\hline $\mathrm{BD}$ & 26.09 & 0.0002 & & & \\
\hline Lack of fit & 0.48 & 0.8334 & & & \\
\hline PSD Coarse & & & & & \\
\hline
\end{tabular}




\begin{tabular}{|c|c|c|c|c|c|}
\hline Bulk Density & $\begin{array}{c}\text { F } \\
\text { Value }\end{array}$ & $\begin{array}{c}\text { p-value } \\
\text { Prob }>\text { F }\end{array}$ & R-Squared & Adj R-Squared & $\begin{array}{c}\text { Model equation in terms } \\
\text { of coded factors }\end{array}$ \\
\hline Model & 95.08 & $<0.0001$ & 0.98 & 0.97 & \multirow{8}{*}{$\begin{array}{c}\text { PSD coarse }=+20.63+ \\
2.57 * \mathrm{~A}-6.88 * \mathrm{~B}-3.79 * \mathrm{D}- \\
2.82 * \mathrm{~A} * \mathrm{~B}+1.29 * \mathrm{~A} * \mathrm{D} \\
-1.31 * \mathrm{~B} * \mathrm{D}\end{array}$} \\
\hline A-Roll pressure & 47.25 & $<0.0001$ & & & \\
\hline B-Roll speed & 339.07 & $<0.0001$ & & & \\
\hline D-Mill speed & 103.06 & $<0.0001$ & & & \\
\hline $\mathrm{AB}$ & 56.89 & $<0.0001$ & & & \\
\hline $\mathrm{AD}$ & 11.99 & 0.0047 & & & \\
\hline $\mathrm{BD}$ & 12.22 & 0.0044 & & & \\
\hline Lack of fit & 0.76 & 0.6711 & & & \\
\hline \multicolumn{6}{|l|}{ PSD Span } \\
\hline Model & 102.08 & $<0.0001$ & 0.97 & 0.96 & \multirow{6}{*}{$\begin{array}{c}\text { Span value }=+4.16+ \\
0.11 * \mathrm{~A}-0.70 * \mathrm{~B}-1.28 * \mathrm{D} \\
-0.20 * \mathrm{~A} * \mathrm{~B}\end{array}$} \\
\hline A-Roll pressure & 2.25 & 0.1555 & & & \\
\hline B-Roll speed & 93.01 & $<0.0001$ & & & \\
\hline D-Mill speed & 305.28 & $<0.0001$ & & & \\
\hline $\mathrm{AB}$ & 7.79 & 0.0144 & & & \\
\hline Lack of fit & 1.23 & 0.4869 & & & \\
\hline \multicolumn{6}{|l|}{ Tablet hardness } \\
\hline Model & 6.91 & 0.0026 & 0.8148 & 0.6970 & \multirow{9}{*}{$\begin{array}{c}\text { Tablet hardness }=+7.26 \\
+0.082 * \mathrm{~A}+0.90 * \mathrm{~B}+ \\
0.32 * \mathrm{C} \\
-0.23 * \mathrm{D}-0.51 * \mathrm{~A} * \mathrm{C}- \\
0.43 * \mathrm{~B} * \mathrm{C}+0.49 * \mathrm{~B} * \mathrm{D}\end{array}$} \\
\hline A-Roll pressure & 0.20 & 0.6661 & & & \\
\hline B-Roll speed & 23.97 & 0.0005 & & & \\
\hline C-VFS speed & 2.99 & 0.1115 & & & \\
\hline D-Mill speed & 1.52 & 0.2429 & & & \\
\hline $\mathrm{AC}$ & 7.49 & 0.0193 & & & \\
\hline $\mathrm{BC}$ & 5.33 & 0.0414 & & & \\
\hline $\mathrm{BD}$ & 6.89 & 0.0236 & & & \\
\hline Lack of fit & 5.37 & 0.0972 & & & \\
\hline
\end{tabular}

Terms with values of "Prob $>$ F" less than 0.0500 are considered as significant and included in the model. However, some terms although un-significant are included for model hierarchy. F-value for the model is the test statistic used to determine whether any term in the model is associated with the response, including covariates, blocks, factor terms, and curvature. F-value for individual terms is used to determine whether the term is associated with the response. The p-value is a probability that measures the evidence against the null hypothesis. Lower probabilities provide stronger evidence against the null 
hypothesis. R2 is the percentage of variation in the response that is explained by the model, while adjusted R2 is adjusted for the number of predictors in the model relative to the number of observations (28).

\section{Effects of process variables on granulate bulk and tapped density}

The results for bulk density on unlubricated granulate range from $0.470 \mathrm{~g} / \mathrm{cm} 3$ till $0.642 \mathrm{~g} / \mathrm{cm} 3$ and $0.570 \mathrm{~g} / \mathrm{cm} 3$ till $0.783 \mathrm{~g} / \mathrm{cm} 3$ for tapped density. There is a clear increase in density in each case compared to the non-compacted blend, pointing to forced densification of the compacted material. ANOVA points to roll pressure, roll speed and vertical feed screw speed as significant model terms, as well as their interactions. Dry mill speed is an important variable as well, having a probability value of less than 0.100 .

However, roll speed is the variable having the most impact on the granule's density. Increasing the roll pressure from 20 bar to 40 bar at roller speed of $12 \mathrm{rpm}$ does not influence the densification significantly. On the other hand, there is a major influence on the density results when roller speed was set to a minimum value of $3 \mathrm{rpm}$. The greatest density for both bulk and tapped can be seen when using a combination of highest roll pressure and lowest roller speed. We can say that this is due to the material compaction process during the compression stage, as creating the particulate bonds and particle rearrangement is time and force-dependent process (25). As the force and contact time increases, any air entrained within the powder is expelled and the ribbon density and strength increase. The influence of the compaction force and the roll speed as most significant factors for granule characteristics have also been confirmed by other authors (29). However, other researchers have reported that also other compactor variables such as roll surface type (30) and screen size (31) could affect the granule particle size and density.

Interactions with the other variables show the complex relationship in the mechanics of roller compaction. Vertical feed screw has a moderate, but noticeable importance in the density of the granules.

Feed screws not only convey the powder material from the compactor storage hopper but they also help deaerate the powder in the process. The deaeration of the powder acts as a mini compactor by precompacting the material just before roll compaction (2). Yet, from the interaction with roller speed it can be noticed that by increasing the roller speed to $12 \mathrm{rpm}$, the change in the VFS speed from 50 to $200 \mathrm{rpm}$ has little impact on the powder density. Additionally, at a roller speed of $3 \mathrm{rpm}$, the increase of the feeding rate even has a negative effect.

Milling is the last step in the process of dry granulation. The importance of a variable with the least contribution to the model must always be taken into consideration. As the ribbons are formed by the roller compaction, they enter the milling chamber and 
into the collection vessel. Even though all of the resulting ribbons are milled throughout the same sieve size, it is expected to obtain resulting granules with different particle size distribution due to different ribbon density.

Many authors have written on the influence of the mill type, mill speed and sieve size on the final granule properties (2). It should be noted that in the cases with high roller pressure and consequently strong, dense ribbons, and where the milling speed was at the lowest value there was a leftover of unmilled granules in the milling chamber. By increasing the milling speed, no such ribbon leftovers in the milling chamber were found. Since only the passed granules were taken into consideration, and the unmilled were discarded the results were the representation of the entire process.

Figure 2 represents interactions graphs and contours for bulk density. The same figure applies for tapped density.
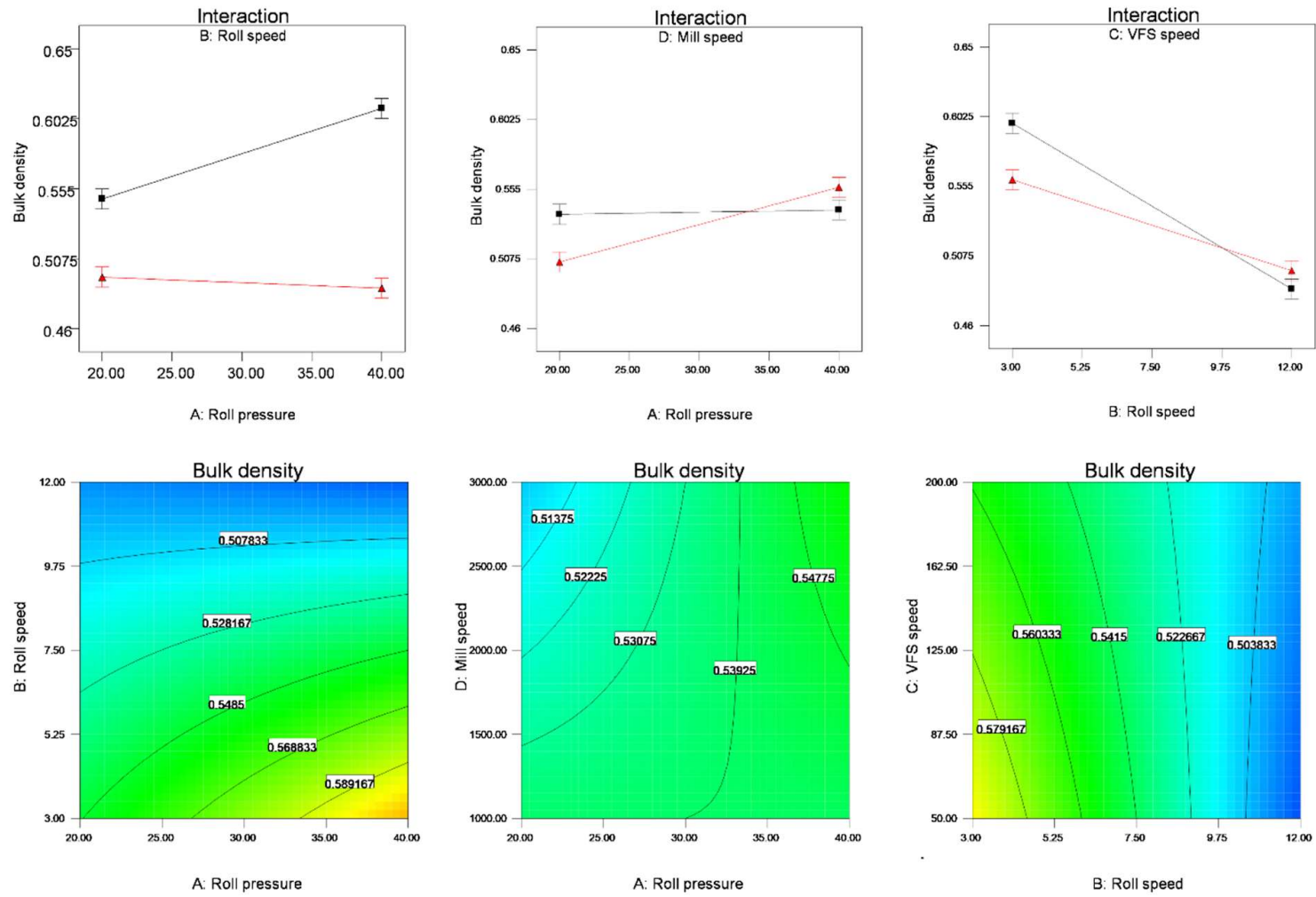

Figure 2 Interactions graphs and contours plots for granulate density 


\section{Effects of process variables on granulate particle size}

Granulate is characterized by particle size using the fines fraction ( $\%$ of the mass of particles with size $<125$ microns), the coarse fraction ( $\%$ of the mass of particles with size $>315$ microns) and particle size distribution span, which is a calculated value used to express the distribution width.

Particle size test on the uncompacted mixture results with more than half of the mixture particles to have size $<125$ microns, and just over $1 \%$ of coarse particles. Span value is very low, implying good, uniform distribution. The experimental models for all the measured variables indicate that roll pressure, roll speed, and mill speed are the main influencing factors. Adequate long ribbons are created in all the cases, and no sticking on the roller surfaces is noticed. However, the density and strength of the ribbons were not measured. In the cases of measured values for the percentage of fines and coarse particles, variable with the biggest impact is roll speed. As discussed earlier, the compaction process is predominantly time and pressure-dependent. By decreasing the time needed for particle bonding and rearrangement, the resulting ribbons are presumably less dense and strong. As the milling process is the final step of the granulation process, it has a large influence on the particle size distribution depending on speed, hammer shape, sieve size, etc. A noticeable interaction can be seen between the mill speed and the roller speed for the results of the fine particle fraction. By increasing the roll speed in cases with low mill speed, the results increase only slightly. However, by increasing the mill speed combined with the increase of the roller speed, there is a noticeable increase in the fine fraction. It seems that the created ribbons are fragile and less dense, and cannot withstand the high impact force of the hammer mill, easily dispersing into primary particles, hence a larger portion of fine fraction. Mill speed has also a very big influence on the span results, implying that increasing the milling speed will create more uniform particles in size and distribution width. 

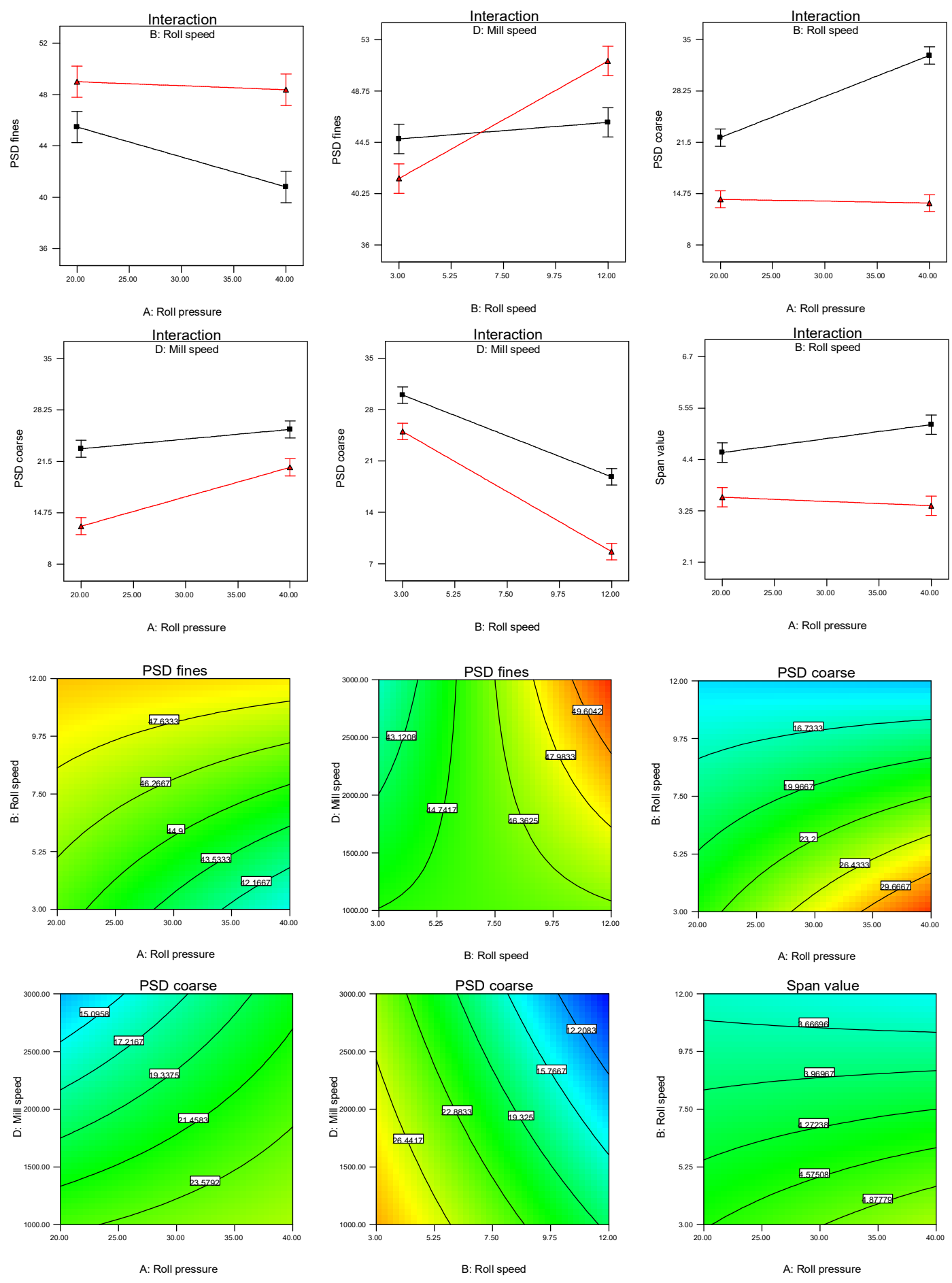

Figure 3 Interactions graphs and contours plots for granulate particle size 


\section{Tableting process}

The machine setting parameters presented as input values in the main compression and dosing volume and results from the measured physical parameters on the tablets are shown in Table V.

Table V Input values and results from the measured physical parameters on the tablets

\begin{tabular}{|c|c|c|c|c|c|c|}
\hline \multirow[b]{2}{*}{ Run } & \multicolumn{2}{|c|}{ Input values } & \multicolumn{4}{|c|}{ Measured physical parameters } \\
\hline & $\begin{array}{c}\text { Main } \\
\text { compression } \\
(\mathrm{kN})\end{array}$ & $\begin{array}{c}\text { Dosing } \\
\text { Volume } \\
(\mathrm{mm})\end{array}$ & $\begin{array}{l}\text { Tablet } \\
\text { mass } \\
(\mathrm{mg})\end{array}$ & $\begin{array}{c}\text { Hardness } \\
(\mathrm{kP})\end{array}$ & $\begin{array}{c}\text { Thickness } \\
\text { (mm) }\end{array}$ & $\begin{array}{c}\text { Disintegration } \\
\text { time } \\
(\mathrm{sec})\end{array}$ \\
\hline mixture & 10.11 & 6.26 & 119.17 & 13.09 & 2.27 & 11 \\
\hline 1 & 10.50 & 5.17 & 120.09 & 7.79 & 2.23 & 25 \\
\hline 2 & 10.00 & 5.58 & 121.64 & 6.68 & 2.25 & 9 \\
\hline 3 & 10.30 & 4.65 & 121.60 & 8.92 & 2.28 & 27 \\
\hline 4 & 10.30 & 4.65 & 120.84 & 8.06 & 2.24 & 32 \\
\hline 5 & 10.10 & 5.46 & 120.42 & 6.95 & 2.24 & 20 \\
\hline 6 & 10.10 & 5.67 & 119.39 & 7.49 & 2.21 & 24 \\
\hline 7 & 10.00 & 5.00 & 120.91 & 3.44 & 2.30 & 46 \\
\hline 8 & 10.30 & 4.94 & 119.96 & 6.23 & 2.23 & 24 \\
\hline 9 & 10.30 & 5.75 & 121.34 & 6.88 & 2.25 & 21 \\
\hline 10 & 10.00 & 6.16 & 119.67 & 6.33 & 2.26 & 35 \\
\hline 11 & 10.70 & 6.16 & 121.18 & 7.44 & 2.29 & 18 \\
\hline 12 & 10.30 & 6.19 & 120.71 & 8.34 & 2.23 & 20 \\
\hline 13 & 10.00 & 5.90 & 119.56 & 8.93 & 2.22 & 24 \\
\hline 14 & 10.10 & 6.07 & 120.37 & 8.38 & 2.23 & 22 \\
\hline 15 & 10.20 & 5.88 & 121.15 & 6.70 & 2.26 & 15 \\
\hline 16 & 10.00 & 6.08 & 121.26 & 6.37 & 2.24 & 15 \\
\hline 17 & 10.10 & 5.24 & 120.15 & 7.09 & 2.23 & 19 \\
\hline 18 & 10.40 & 5.31 & 120.65 & 5.61 & 2.24 & 17 \\
\hline 19 & 10.10 & 5.34 & 119.77 & 6.02 & 2.23 & 13 \\
\hline 20 & 10.30 & 5.34 & 120.88 & 8.89 & 2.27 & 31 \\
\hline SD & 0.19 & 0.51 & 0.74 & 1.84 & 0.02 & 8.66 \\
\hline
\end{tabular}


Seeing from the results, we can notice that the uncompacted mixture produces the hardest tablets, compared to any other case. This is not uncommon however, several authors have tried to explain this loss of tabletability, sometimes significantly, after being dry granulated using roller compaction or slugging (32). Many authors believe that this tabletability loss is due to "work hardening" $(1,33,34)$, a theory suggesting that plastic deformation of particles during the process of pelleting or roller compaction introduces a significant amount of defects to the particles. The high concentration of defects, in turn, hardens particles and reduces plasticity that is critical for the permanent deformation of granules during the subsequent compaction process. However, some authors in a subsequent study propose that granule size enlargement is responsible for the phenomenon (32).

The ANOVA for the factorial model as seen in Table IV shows only roll speed as the main significant model term. The influence on the roller speed as initial compression speed on the tablet hardness can be correlated with the mechanism of particle compression and rearrangement, ribbon density and strength, as well as with the amount of initial compaction before tableting. There is no significant difference in tablet height, indicating that all of the granulates achieve the same packing density during the tableting process. According to the authors' experience, the tablet hardness achieved from all of the mixtures is acceptable. All of the samples disintegrated in less than one minute.

\section{SUMMARY AND CONCLUSION}

Granulation using the roller compaction process is a widely used manufacturing process. In the process of roll compaction, many factors may affect the final product. In this study, the critical process parameters were identified and their influence quantified using two-level factorial design.

The results demonstrate how the physical properties of the granulate are influenced by the processing parameters and optimisation of the process parameters during the compaction process can be used to predict the physical properties of the granulate.

Roller compaction pressure and roll speed were the parameters most often identified as the critical parameters affecting granules properties. These process parameters and their interactions influence the characteristics of the resulting granules in terms of powder density and particle size. Mill speed also must be taken into account when trying to correlate the entire compaction process with the final product properties. While mill process at low speed may lack sufficient impact force to break strong ribbons, at very high speed it can pulverize the granules into primary particles and increase the fine particles fraction. The authors recommend trying several combinations of mill knives and sieve sizes to be tested before an optimisation study. 
Vertical feeding screw speed is a parameter that ensures proper feeding of the compaction rolls and influences the density of the granules. Low feeding speed will result in inconsistent compacting process and interruptions in the ribbons, yet very high feeding speed will tamper the powder into the pre-compaction area and could lead to a blockage in the process.

During the tableting process, the fixed process parameters resulted in tablets with different tablet properties, relating to the different properties of the granules.

However, the observation was the lack of direct correspondence between the physical properties of the tablets and the manufacturing parameters of the roller compaction process. A future focus should be on deeper characterisation of the granules and various combinations of compaction pressure as well as dwell time ranges during the process of manufacturing of tablets.

By defining the critical process parameters in the screening phase, the formulators could additionally continue in establishing the design space using response surface modelling and use the data and knowledge gained further in the manufacturing scale-up process and product lifecycle.

From a QbD perspective, knowing the influence of each of the process variables, defining the operational range and optimising each of the parameters in order to achieve the desired goal, can lead to utilising the process of roller compaction as a robust tool for pharmaceutical manufacturing. Although in this case, the authors performed the screening and identification of the factors influencing the granule and tablet properties using a placebo, the principles would be the same when using a formulation containing active pharmaceutical components.

\section{Acknowledgement}

The authors would like to acknowledge to the support of ALKALOID AD Skopje and the Head of Research and Development Mrs. Sonja Ugarkovic for all the support during this study.

\section{Bibliography}

1. Parikh DM. Handbook of pharmaceutical granulation technology. Handbook of Pharmaceutical Granulation Technology, Second Edition. 2005. 1-625 p.

2. Swarbrick J, editor. Encyclopedia of Pharmaceutical Technology, Third Edition. 3rd Editio. CRC Press; 2007. 4128 p. 
3. Rowe JM, Crison JR, Carragher TJ, Vatsaraj N, Mccann RJ, Nikfar F. Mechanistic insights into the scale-up of the roller compaction process: A practical and dimensionless approach. J Pharm Sci. 2013;

4. $\quad$ Pietsch W. Roll Pressing. John Wiley \& Sons; 1976. 148 p.

5. Ph.Eur. No Title. In: European Pharmacopoeia. 9.7. Council of Europe; 2019.

6. Freeman T, Vom Bey H, Hanish M, Brockbank K, Armstrong B. The influence of roller compaction processing variables on the rheological properties of granules. Asian J Pharm Sci. 2016;

7. Freitag F, Kleinebudde P. How do roll compaction/dry granulation affect the tableting behaviour of inorganic materials? Comparison of four magnesium carbonates. Eur J Pharm Sci. 2003;

8. Lee KT, Ingram A, Rowson NA. Twin screw wet granulation: The study of a continuous twin screw granulator using Positron Emission Particle Tracking (PEPT) technique. Eur J Pharm Biopharm. 2012;

9. Standard Practice for Determining Data Criteria and Processing for Liquid Drop Size Analysis. No Title [Internet]. 13521BC. Available from: http://www.astm.org/cgi-bin/resolver.cgi?E79903(2015)

10. Shangraw RF, Demarest DA. A survey of current industrial practices in the formulation and manufacture of tablets and capsules. Pharm Technol. 1993;(17):32-44.

11. Parikh DM. Handbook of Pharmaceutical Granulation Technology. Taylor \& Francis. 2010.

12. Reier GE, Shangraw RF. Microcrystalline cellulose in tableting. J Pharm Sci [Internet]. 1966 May 1;55(5):510-4. Available from: https://doi.org/10.1002/jps.2600550513

13. Marshall K, Sixsmith D. The flow properties of microcrystalline cellulose powders. J Pharm Pharmacol [Internet]. 1976 Oct 1;28(10):770-1. Available from: https://doi.org/10.1111/j.20427158.1976.tb04045.x

14. Armstrong NA, Palfrey LP. The effect of machine speed on the consolidation of four directly compressible tablet diluents. J Pharm Pharmacol. 1989 Mar;41(3):149-51.

15. De Boer AH, Bolhuis GK, Lerk CF. Bonding characteristics by scanning electron microscopy of powders mixed with magnesium stearate. Powder Technol [Internet]. 1978;20(1):75-82. Available from: http://www.sciencedirect.com/science/article/pii/0032591078800114

16. Khan KA, Rhodes CT. Comparative evaluation of some direct compression diluents. Pharm Acta Helv. 1976;51(1):23-6.

17. GANDERTON D, SELKIRK AB. The effect of granule properties on the pore structure of tablets of sucrose and lactose. J Pharm Pharmacol [Internet]. 1970 May 1;22(5):345-53. Available from: https://doi.org/10.1111/j.2042-7158.1970.tb08536.x

18. Bolhuis GK, Reichman G, Lerk CF, Van Kamp H V, Zuurman K. Evaluation of Anhydrous $\alpha$ Lactose, A New Excipient in Direct Compression. Drug Dev Ind Pharm [Internet]. 1985 Jan 1;11(8):1657-81. Available from: https://doi.org/10.3109/03639048509057692

19. Bolhuis GK, Lerk CF, Moes JR. Comparative evaluation of excipients for direct compression. Pharm Weekbl [Internet]. 1979 Dec;1(1):1473-82. Available from: https://doi.org/10.1007/BF02293487

20. Gillard J, Delattre L, Jaminet F, Roland M. [Parameters influencing the flow rate of diluent agents used in direct compression]. J Pharm Belg. 1972;27(6):713-42. 
21. HARDMAN JS, LILLEY BA. Deformation of Particles during Briquetting. Nature [Internet]. 1970;228(5269):353-5. Available from: https://doi.org/10.1038/228353b0

22. York P. Particle slippage and rearrangement during compression of pharmaceutical powders. J Pharm Pharmacol. 1978 Jan;30(1):6-10.

23. Cole ET, Rees JE, Hersey JA. Relations between compaction data for some crystalline pharmaceutical materials. Pharm Acta Helv. 1975;50(1-2):28-32.

24. Alderborn G, Nyström C. Studies on direct compression of tablets XIV. The effect of powder fineness on the relation between tablet permeametry surface area and compaction pressure. Powder Technol [Internet]. 1985;44(1):37-42. Available from: http://www.sciencedirect.com/science/article/pii/003259108585018X

25. Alderborn G, Nystrom C, editors. Pharmaceutical Powder Compaction Technology (Drugs and the Pharmaceutical Sciences). 1st ed. Taylor \& Francis; 1995. 634 p.

26. Vromans H, Bolhuis GK, Lerk CF, Kussendrager KD. Studies on tableting properties of lactose. VIII. The effect of variations in primary particle size, percentage of amorphous lactose and addition of a disintegrant on the disintegration of spray-dried lactose tablets. Int $\mathrm{J}$ Pharm [Internet]. 1987;39(3):201-6. Available from: http://www.sciencedirect.com/science/article/pii/0378517387902171

27. Haleblian JK, Goodhart FW. Pharmaceutical sciences - 1974: Literature review of pharmaceutics. J Pharm Sci [Internet]. 1975 Jul 1;64(7):1085-148. Available from: https://doi.org/10.1002/jps.2600640703

28. 2019 Minitab L. Minitab 18 Support [Internet]. [cited 2019 May 14]. Available from: https://support.minitab.com/en-us/minitab/18/help-and-how-to/modeling-statistics/doe/howto/factorial/analyze-factorial-design/interpret-the-results/all-statistics-and-graphs/analysis-ofvariance-table/

29. Weyenberg W, Vermeire A, Vandervoort J, Remon JP, Ludwig A. Effects of roller compaction settings on the preparation of bioadhesive granules and ocular minitablets. Eur J Pharm Biopharm. 2005;

30. Rambali B, Baert L, Jans E, Massart DL. Influence of the roll compactor parameter settings and the compression pressure on the buccal bio-adhesive tablet properties. Int J Pharm. 2001;

31. Souihi N, Josefson M, Tajarobi P, Gururajan B, Trygg J. Design space estimation of the roller compaction process. Ind Eng Chem Res. 2013;

32. Sun C, Himmelspach MW. Reduced tabletability of roller compacted granules as a result of granule size enlargement. J Pharm Sci. 2006;

33. Malkowska S, Khan KA. Effect of re-conpression on the properties of tablets prepared by dry granulation. Drug Dev Ind Pharm. 1983;

34. Kleinebudde P. Roll compaction/dry granulation: Pharmaceutical applications. European Journal of Pharmaceutics and Biopharmaceutics. 2004. 


\title{
Ispitivanje uticaja kritičnih parametara procesa prilikom kompakcije rolera na fizičke karateristike granula i tableta primenom ekpserimentalnog dizajna
}

\author{
Elizabeta Atanaskova*, Dejan Kostovski, \\ Natasa Anevska-Stojanovska
}

Istraživanje i razvoj, Alkaloid AD-Skoplje, Bul. Aleksandar Makedonski 12, 1000 Skoplje, Republika Severna Makedonija

*Autor za korespondenciju: Elizabeta Atanaskova, e-mail: eatanaskova@Alkaloid.com.mk

\section{SAŽETAK}

Farmaceutska industrija koristi različite metode suve i vlažne granulacije. Iako je suva granulacija, odnosno kompakcija na valjcima (engl. roller compaction) široko rasprostranjen proces granulacije, procena kritičnih parametara procesa je izazovna zbog složene interakcije između svakog pojedinačnog parametra.

Proizvod procesa kompakcije na valjcima su komprimati sa različitim karakteristikama koje se zasnivaju na varijaciji ulaznih parametara. Svojstva finalnog proizvoda su direktno povezana sa procesnim parametrima koji se koriste tokom suve granulacije. Razumevanje interakcije između parametara omogućava pravilnu kontrolu procesa kompakcije na valjcima.

Cilj ove studije je da predstavi primenu eksperimentalnog dizajna u razvoju procesa kompakcije na valjcima. U tu svrhu, korišćen je pun faktorski dizajn i dva nivoa za svaki faktor za procenu uticaja procesnih parametara kao što su pritisak i brzina valjaka, brzina obrtnog elementa hranilice, i brzina elementa za usitnjavanje na fizičke karakteristike intermedijarnog i konačnog proizvoda.

Rezultati su pokazali da je brzina valjaka parametar koja ima najveći uticaj na gustinu granula. Veličina čestica granulata u velikoj meri zavisi od varijacije pritiska valjaka, njegove brzine i brzine elementa za usitnjavanje. Povećanje brzine elementa za usitnjavanje dovodi do ujednačene raspodele veličine čestica. Nakon procesa kompresije granula u tablete i analize podataka, brzina valjaka pokazala se kao faktor sa najznačajnijim uticajem na čvrstinu tableta.

Ključne reči: kompakcija na valjcima, suva granulacija, eksperimentalni dizajn, fizičke karakteristike proizvoda. 